expert knowledge, and in so far as it is prevented from specializing is saved from onesidedness. Even from the point of view of research we need general libraries, highly specialized libraries and intermediate collections; libraries from which books can be borrowed and those from which they cannot. The most desirable lines for their development can only be decided after careful examination, subject by subject, of the needs of those who use them. A general survey of Great Britain's needs would, as Mr. Woledge suggests, and has already been strongly recommended as an urgent need in the McColvin report, be of great value in helping to make the best use of available funds, and his warning that funds cannot be unlimited or expended extravagantly is timely. Mr. Woledge scarcely formulates the questions which must be answered before either large or small libraries can take the fullest part in a national system of providing books and information, but he shows that all engaged in library work should consider more closely their functions, not only in relation to special needs, but also to those of the nation as a whole and the contribution they are best equipped to make to national needs.

\section{Radiolocation and Shipping Risks in Peace-time}

The fifteenth report from the Select Committee on National Expenditure for the session 1942-43, dealing with the salvage of ships and cargoes, contains important references to developments in radiolocation which seem likely to reduce shipping casualties, and thus to decrease the amount of salvage work to be done in normal times. As a decision on the future use of the large quantity of radiolocation equipment owned by the Government is urgently required, evidence was heard from eminent scientific workers and from representatives of Trinity House on the possibility of using it to increase the safety of navigation after the War under conditions of low visibility. The Committee was assured that much of this equipment would be of value for such purposes, and accordingly it recommends that the Government should examine the question of the post-war use of radiolocation apparatus for safety at sea, together with the making of any international agreements required. The bulk of the report gives an interesting picture of the general salvage position in 1939 and during the War, which does not always reflect credit on the Admiralty. While the Committee resists the proposal to create a monopoly for British salvage enterprises in British territorial waters, unless the hopes of a general breakdown of monopolies and barriers to commercial activity are disappointed, it advances proposals for maintaining British salvage enterprises in so sound and efficient a state that underwriters will not be obliged to call on the services of foreign firms.

\section{The Royal Irish Academy}

THE meeting of the Royal Irish Academy on November 8 was devoted to a celebration of Hamilton's discovery of quaternions. A well-attended meeting which included $\mathrm{Mr}$. De Valera and other Ministers was addressed by the president, Dr. R. I. Best, who read messages from Prof. G. D. Birkhoff of Harvard and Prof. J. L. Synge of Ohio State University. An account of the Dublin mathematical school in the early nineteenth century with reference to the work not of Hamilton only but also of
McCullagh, Lloyd, Jellett, Haughton, Salmon, etc., was given by Prof. A. J. McConnell. Prof. A. W. Conway read a paper on quaternions and matrices in which he showed that the use of quaternion methods makes for great simplification of the meson matrices. A paper by Prof. E. T. Whitaker on the sequence of ideas in the discovery of quaternions and a note on quaternions by Prof. G. D. Birkhoff were also read. A paper by Rev. J. R. Colthurst on the Inconsian calculus of Sir William Rowan Hamilton was read in title. A communication from Prof. F. D. Murnaghan of Johns Hopkins University, entitled "A Modern Presentation of Quaternions", owing to postal delays was received too late for the meeting, but will be included in the report of the proceedings which will be printed.

\section{The Haffkine Institute, Bombay}

THE report for 1940-41 of the Haffkine Institute at Parel, Bombay, shows a record of widely useful work, of expansion of departments to meet the needs of the War and of increased production of sera, antitoxins and vaccines for the Forces. A new department for the manufacture on a large scale of antitoxins, toxoids and sera has been begun and the Institute has found that it can produce these at a cost one half to one sixth of that of the imported products. The Department of Chemotherapy is also new ; it reports that sulphathiazole is effective for the treatment of bubonic plague. Sulphonamide products are being synthesized, their commercial production is being investigated and new compounds in this series are being sought. The production of Haffkine's antiplague vaccine and other work on plague occupy, perhaps naturally, a considerable part of this report. But interesting work is also being done in an endeavour to replace the standard malarial remedies, the supply of which has been reduced by the War. It is claimed that sulphathiazole and another sulphonamide prepared by the Institute have remarkable curative effects on monkey malaria without the relapses which follow the treatment of monkeys with atebrin and quinine.

\section{Poliomyelitis in the United States}

According to official information, the incidence of this disease in July reached epidemic proportions in several south-western States, and the figures for the country during the first six and a half months were the highest in twelve years. Figures for the week ending July 17 showed 297 cases in the United States as compared with 245 for the preceding week ; 231 cases or 94 per cent were reported from three States, namely, Texas with 102, California with 90 and Oklahoma with 39 . For the first twenty-eight weeks of $1943,1,626$ cases were listed for the entire country.

\section{Islands and Peoples of the East Indies}

WAR Background Studies of the Smithsonian Institution, No. 14, relates the story of the East Indies and their inhabitants. The account does not pretend to be other than superficial, but for the intelligent reader wishing to know something about an area that may at any time now come to figure largely in the war news, this book can be confidently recommended. It contains a great deal of information and is beautifully illustrated. 